\title{
Research on Performance and Emission of Ic Engine using Porous Medium Cylinder Head
}

\author{
S.Prabhu, T.Suresh, B.Prabhu, S.Ramanathan, F.Justin Dhiraviam
}

\begin{abstract}
At present IC engines are experiencing with partial ignition and irregular temperature circulation inside the engine cylinder due to improper mixing of air and fuel mixture. Due to this effect, $\mathrm{NO}_{x}, \mathrm{CO}$ and Unburned hydro carbons will be released into the atmosphere. Excessive soot formation also takes place in the IC engine. To perform the homogeneous combustion inside the engine cylinder the new Porous Medium concept has been proposed. Porous Medium engine concept is mainly for reducing the emissions and improving the performance characteristics of the IC engine. Gun Metal Porous Medium has been introduced at the top of the Kirloskar 5BHP diesel engine cylinder head. When compared to conventional engine, reduction of total fuel consumption quantity up to 13\%, Specific fuel consumption quantity up to $12 \%$, increment in Brake thermal efficiency up to $12 \%$ and Indicated thermal efficiency up to $6 \%$ are obtained during part load operations. When compared to conventional engine, Mechanical efficiency has been increased up to 8\%, NOx level gets reduced up to $53 \%$ and $\mathrm{CO}_{2}$ level gets decreased up to $46 \%$ from no load to full load operations.
\end{abstract}

Keywords - IC Engine; Gunmetal Porous Medium cylinder head; Performance Investigation; Emission Control

\section{ABBREVIATIONS}

$\mathrm{IC}$

Internal Combustion

PM

Porous Medium

TDC

Top Dead Centre

$\mathrm{SiC}$

Silicon Carbide

$\mathrm{UHC}$

Unburned Hydro Carbon

$\mathrm{CO}$

Carbon Monoxide

NOx

Oxides of Nitrogen

CHEMKIN

Chemical Kinetics

Revised Manuscript Received on September 10, 2019.

S.Prabhu, Assistant Professor, Department of Mechanical Engineering, Kumaraguru College of Technology, Coimbatore, Tamilnadu, India. (Email: prabhusmechanical@gmail.com)

T.Suresh, Assistant Professor, Department of Mechanical Engineering, Kamaraj College of Engineering and Technology, Madurai, Tamilnadu, India.

B.Prabhu, Assistant Professor, Department of Mechanical Engineering, Kamaraj College of Engineering and Technology, Madurai, Tamilnadu, India.

(Email: prabhumech@kamarajengg.edu.in)

S.Ramanathan, Assistant Professor, Department of Mechanical Engineering, Kumaraguru College of Technology, Coimbatore, Tamilnadu, India.

(Email: ramanathan.s.mec@kct.ac.in)

F.Justin Dhiraviam, Assistant Professor, Department of Mechanical Engineering, Sri Eshwar College of Engineering, Coimbatore, Tamilnadu, India.

(Email: justindhiraviam.f@gmail.com)
(Email: sureshmech@kamarajengg.edu.in

$\begin{array}{ll}\text { TFC } & \text { Total Fuel Consumption } \\ \text { SFC } & \text { Specific Fuel Consumption } \\ \text { BHP } & \text { Brake Horse Power } \\ \text { FP } & \text { Fuel Power } \\ \text { IP } & \text { Indicated Power } \\ \text { BTE } & \text { Brake Thermal Efficiency } \\ \text { ITE } & \text { Indicated Thermal Efficiency } \\ \text { ME } & \text { Mechanical Efficiency } \\ \text { VE } & \text { Volumetric Efficiency } \\ \text { PS } & \text { Particulate Substance } \\ \text { EFF } & \text { Effluent } \\ \text { CO2 } & \text { Carbon Dioxide } \\ \text { VMC } & \text { Vertical Milling Machine }\end{array}$

NOMENCLATURE

$\begin{array}{ll}\mathrm{N} & \begin{array}{l}\text { Speed } \\ \mathrm{T}\end{array} \\ \mathrm{t} & \text { Torque } \\ \mathrm{L} & \text { Time Taken for 10cc of fuel supplied } \\ \mathrm{d} & \text { Stroke Length } \\ & \text { Diameter of Bore }\end{array}$

SYMBOLS

$\begin{array}{ll}\rho & \text { Density of diesel } \\ \mathrm{Cd} & \text { Co efficient of discharge } \\ \rho \text { air } & \text { Density of air }\end{array}$

\section{INTRODUCTION}

At present diesel engines are operating with very high fuel injection technologies like homogeneous charge compression ignition, high pressure fuel injection and common rail direct injection for efficient operation. But, Emissions from conventional diesel engines can only be enhanced by catalytic converters. Such treatments, on the other hand, outcome in high costs and moderately low adaptation effectiveness. The porous medium combustion

Published By: 
technology is an efficient method for reducing the emission characteristics and improving the performance of the engine. The PM combustion technology provides information about the homogeneous combustion. The new porous medium concept has been proposed by Dr. Franz Drust. Researchers are trying various technologies to accomplish homogenous mixture formation, combustion and subsequently lower particulate emission. One such technique to realize homogenous mixture formation and lower particulate emission from diesel engines is porous medium combustion [1]. Silicon Carbide, Zirconium oxide and Alumina based porous structures are widely used for improving performance of the IC engine. Applications of highly porous structure to IC engine field, Definitions of internal combustion engine ignition modes, Different types of porous materials used in the IC engine applications [1]. [2] Most significant engine processes that may be supported by the PM-technology are power recirculation, fuel injection, fuel vaporization, flame transport properties and flame propagation. These processes are very much important to make combustion as homogeneous. The working principle of PM engine, the types of combustion chambers are available in the PM combustion technology are very much important. [3] Working principle of PM engine, the types of combustion chambers are PM engine with open combustion chamber and PM engine with closed combustion chamber. In IC engines, there are two different ways of positioning are available for fixing the porous medium. [3] One is Piston region (PM moves with piston) and cylinder head (PM stationary) are the two different ways of positioning the porous medium in the IC engine. There are different types of porous ceramic materials are presently existing for different applications. [4] Porous ceramic materials are used in the IC engines for increasing the fuel economy and more compact designs with lower capacity of cooling. The porous ceramic materials are being introduced inside the combustion chamber to achieve the homogeneous combustion. To achieve homogeneous combustion in the IC engine, properties of porous medium has to be considered. [4] Porous medium has lot of special characteristics large heat capacity, large specific surface area, large porosity, high mechanical, thermal stability and excellent heat transfer properties. In this project, gun metal porous medium has been introduced at the top of the engine cylinder head. Gun metal porous medium improves the emission as well as performance characteristics of the IC engine. [5] Zirconium oxide porous material is used in the kirloskar 5BHP diesel engine piston with appropriate locking mechanism for making homogeneous combustion. Due to this arrangement, particulate substance, soot formations gets reduced. PM combustion technology is not only used in IC engine. [6] The various applications of porous medium combustion technologies are heat exchangers, oil and gas recovery, hydrogen production, gas turbine, lighting and solid fuel combustion. Simulation of absorbent medium ignition in IC engine is quite effortless process for studying the emissions characteristics. [7] It gives information about the simulation of direct fuel injection in an IC engine equipped with a chemically inert PM installed in the cylinder head for homogeneous and stable combustion and methane fuel is injected directly through a hot PM which is mounted in the engine cylinder head The salient parameters in PM combustion technologies are High combustion efficiency, super adiabatic flame temperature, emissions and performance. These are all found out using the KIVA - 3V code. It is one of the simulation software for findind out the important parameters. There are various parameters are available to study the performance of the PM engine.[8] Buy varying the injection timing on mixture formation, pressure and temperature distribution in both phases of PM, crank angle, load and compression ratio. In any systems, exergy analysis will play the vital role. Exergy in the sense, it is the maximum available produced from the system.[9] In the porous medium combustion, losses will create the irreversibiltiy in the system. from this journal, periodic type PM combustion chamber will get the lower irreversibility than that of permanent contact PM combustion chamber. There are different types of liquid and gaseous fuels are used for analyzing the PM engine. In this project, Diesel itself injected at the time fuel injection. Biodiesel and Blending of fuel is not used in this project. [10] PM engine has been operated with natural gas $\left(\mathrm{CH}_{4}\right)$. Simulation results are obtained for the following variable like pore diameter and fuel injection timing. Emissions were gets reduced with predominant manner. [11] PM engine has been operated with kerosene fuel for reducing the nitric mono oxides, carbon monoxides and soot. Silicon carbide coated carbon foam used as a porous inert medium. The NOx and CO emissions were measured to optimize the porous medium configuration with minimum emissions. Salient properties and comparison of porous medium material are temperature, density, thermal conductivity, specific heat vital for selecting the PM for homogeneous combustion. [12] Comparison of all the PM with their operating values has been given for selection of PM. Analysis of turbulent as well as laminar flow in the inert porous medium is very much useful for studying the reaction kinetics of the PM. [13] this journal provides the information about reaction kinetics, fuel consumption quantity has been found out using Arrhenius expression which contains the product of two values, namely the mass fraction of the fuel and of the oxidant. Porous media combustion (PMC) has interesting advantages compared with free flame combustion due to higher burning rates, increased power dynamic range, extension of the lean flammability limits, and low emissions of pollutants. [14] All factors are can be easily found out using of modelling of PM combustion and also the gas phase energy equations, solid phase energy equations and continuity equations plays vital role in the modelling of PM. In the Present study, Gun Metal Porous Medium has been introduced at the top of the Kirloskar 5BHP diesel engine cylinder head. Performance and Emission Characteristics of IC engine has been analyzed with the porous medium.

\section{METHODOLOGY}

Modification of IC engine Cylinder head with the Gun Metal Porous Medium is carried out. The possible way of positioning the PM - Combustion Chamber in IC engines:

Published By: 
Cylinder Head (Porous Medium is Stationary) and Piston (Porous Medium moves with piston). Some portion (35 mm x $16 \mathrm{~mm} \times 3 \mathrm{~mm}$ ) of the material is removed from the engine cylinder head that place will be occupied by the Gun metal porous material. Location of the porous medium mentioned in the pro - E model Shape of the porous medium will be in the shape of rectangular as shown in figure 2.1. Figure 2.2 shows an actual arrangement of PM structure in Cylinder head. Calculations have been made for with / without inserting the porous medium. Finally, compare the performance and emission characteristics of IC engine as shown in figure 2.3 have been analyzed with / without inserting the porous medium. Specifications of IC engine are shown in Table 2.1.

Table 2.1. Specifications of IC Engine

\begin{tabular}{|c|l|c|}
\hline S. No & \multicolumn{1}{|c|}{ Description } & Values \\
\hline 1. & No ofCylinder & Single \\
\hline 2. & Type & Vertical Engine \\
\hline 3. & No of Strokes & 4 \\
\hline 4. & BHP & $5(0 \mathrm{r}) 3.7 \mathrm{~kW}$ \\
\hline 5. & Compression Ratio & $16.5: 1$ \\
\hline 6. & Cylinder bore diameter & $80 \mathrm{~mm}$ \\
\hline 7. & Stroke of piston & Stroke of piston \\
\hline 8. & RatedRPM & 1500 \\
\hline 9. & Type of Cooling & Water Cooled Engine \\
\hline
\end{tabular}

\section{1. properties of porous medium}

The Selected Porous Medium is GUN METAL (88\% Cu, $10 \% \mathrm{Sn}, 2 \% \mathrm{Zn}$ ) and Table 2.2 shows the properties of gunmetal as given below.

Table 2.2. Properties of Gun metal

\begin{tabular}{|l|l|l|}
\hline $\begin{array}{l}\text { S. } \\
\text { No }\end{array}$ & Properties & Values \\
\hline 1. & Temperature & $1000{ }^{0} \mathrm{C}$ \\
\hline 2. & Tensile Strength & 221 to $310 \mathrm{MPa}$ \\
\hline 3. & Compression Strength & $275 \mathrm{MPa}$ \\
\hline 4. & Fatigue Strength & 69 to $169 \mathrm{MPa}$ \\
\hline 5. & Hardness & $65-74$ \\
\hline 6. & Density & $8.72 \mathrm{~g} / \mathrm{cm}^{3}$ \\
\hline 7. & Strength to Weight ratio & $36 \mathrm{kN}-\mathrm{m} / \mathrm{kg}$ \\
\hline
\end{tabular}
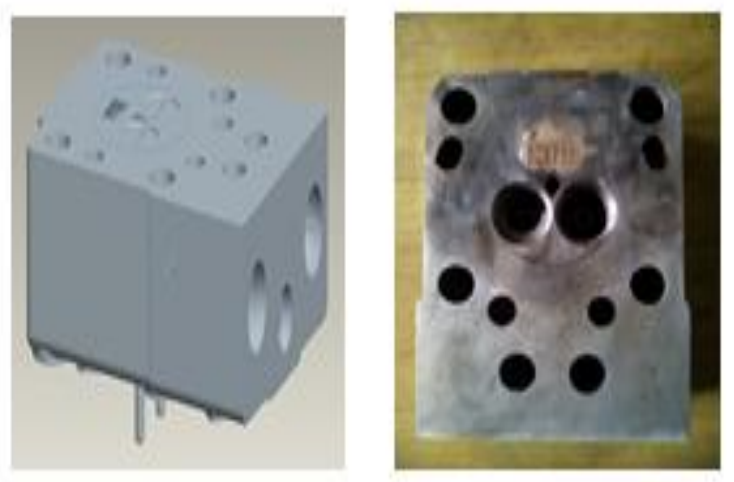

Fig. 2.1. 3D Model of PM cylinder head , Fig.2.2. Actual PM cylinder head

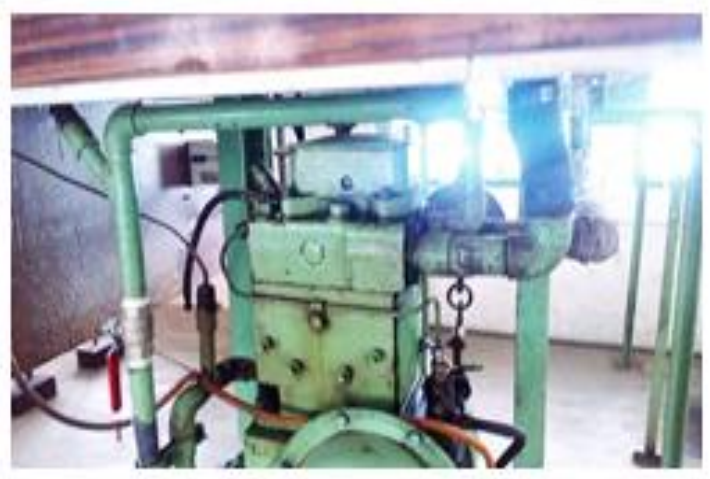

Fig. 2.3. Kirloskar 5BHP Diesel Engine

\section{EXPERIMENTATION}

We have experimentally investigated the performance characteristics of IC Engine with and without inserting porous medium on cylinder head for various working load conditions. The obtained results are shown in Table 3.1, 3.2.

\subsection{Formulae Used}

Max Load Calculation:

$$
\text { Brake Power }(\mathrm{BP})=[2 * \pi * \mathrm{~N} * \mathrm{~T}] / 60
$$

$$
-----3.1
$$$$
\mathrm{N} \quad-\quad \text { Speed in } \mathrm{rpm}
$$

$\mathrm{T}-$ Torque in Nm (Force * Radius)

Force $=$ mass $*$ Acceleration due to gravity

Radius $=0.1942 \mathrm{~m}$

Max Load of the engine $=12.29 \mathrm{Kg}$

TFC $=10 / \mathrm{t} \quad * 10^{\wedge}-6 * \rho \quad(\mathrm{kg} / \mathrm{s})$

Where, $\mathrm{t}$ - Time Taken for 10cc Fuel Supplied (Sec) $\rho-$ Density of fuel $\left(832 \mathrm{Kg} / \mathrm{m}^{\wedge} 3\right)$

$\mathrm{SFC}=\mathrm{TFC} /$ Brake Power $(\mathrm{kg} / \mathrm{kW} \mathrm{s})$ -----3.3

$\mathbf{I P}=$ Brake Power + Friction Power $-----3.4$

$\mathbf{F P}=$ TFC $*$ Calorific Value of fuel $(43,500 \mathrm{KJ} / \mathrm{KG})$ $------3.5$

BTE $=($ Brake Power $/$ Fuel Power $) * 100$ 3.6

ITE $=($ Indicated Power $/$ Fuel Power $) * 100$ -------3.7

$\mathbf{M E}=($ Brake Power $/$ Indicated Power $) * 100$ -------3.8

Actual air intake $=\mathrm{Cd} *$ pair $*$ Orifice area $*(2 * \mathrm{~g} * \mathrm{~h}) \wedge$ (0.5) ----3.9

Where, $\mathrm{Cd}-\mathrm{Co}$ efficient of discharge $=0.62$ Density of air $=1.23 \mathrm{Kg} / \mathrm{m}^{\wedge} 3$

Area of the Orifice $=(\pi / 4)^{*} \mathrm{~d}^{\wedge} 2 ; \mathrm{d}=20 \mathrm{~mm}$

Theoretical Air Intake $\left.=\left((\pi / 4) * \mathrm{~d}^{\wedge} 2\right) * \mathrm{~L} *(\mathrm{~N} / 60)\right)^{*}$ pair ------3.10

Where, $\mathrm{L}=110 \mathrm{~mm}$ $\mathrm{d}=80 \mathrm{~mm}$

$\mathbf{V E}=$ Actual air intake/Theoretical air intake ------ 3.11

Air fuel ratio $=$ Actual air intake $/$ TFC

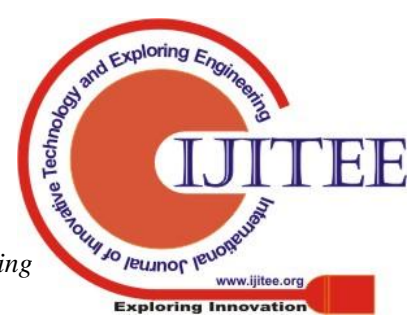


Table 3.1, shows the experimental analysis of Kirloskar 5BHP diesel engine without inserting the porous medium. At maximum load $(10 \mathrm{~kg})$, we find the different kinds of efficiencies of conventional engine are $34 \%$ Brake thermal efficiency, 58\% Indicated thermal efficiency and 58\% Mechanical efficiency.

\begin{tabular}{|c|c|c|c|c|c|c|c|c|c|c|c|c|c|}
\hline S.NO & $\mid \begin{array}{c}\mathrm{LOAD} \\
(\mathrm{K} g)\end{array}$ & $\mid \begin{array}{l}\text { SPEED } \\
(\mathrm{RPM})\end{array}$ & $\begin{array}{c}\text { BRAKE } \\
\text { POWER } \\
(\mathrm{kW})\end{array}$ & \begin{tabular}{|c|} 
TMME \\
TAKEN \\
FOR 10CC \\
FUEL \\
SUPPLIED \\
(Sec)
\end{tabular} & $c \mid \begin{array}{c}\text { TOTAL FUEL } \\
\text { CONSUM } \\
\text { (Kg/s) }\end{array}$ & $\begin{array}{c}\text { SPECIFIC } \\
\text { FUEL } \\
\text { CONSLM } \\
\text { (Ko/kW- } \\
\text { hr) }\end{array}$ & \begin{tabular}{|c|} 
INDICATED \\
POWER (kW)
\end{tabular} & $\begin{array}{c}\text { FUEL } \\
\text { POWER } \\
(\mathrm{kW})\end{array}$ & \begin{tabular}{|c|} 
BRAKE \\
THERMAL \\
EFFICENCY \\
$(\%)$
\end{tabular} & $\begin{array}{c}\text { INDICATED } \\
\text { THERMAL } \\
\text { EFFCIENCY } \\
(\%)\end{array}$ & $\begin{array}{l}\text { MECHANICAL } \\
\text { EFFCIENCY } \\
(\%)\end{array}$ & $\begin{array}{l}\text { VOL } \\
\text { EFF } \\
(\%)\end{array}$ & \begin{tabular}{|c|} 
AIR \\
FULL \\
RATIO
\end{tabular} \\
\hline 1 & 0 & 1644 & \begin{tabular}{|l|}
0.000 \\
\end{tabular} & 65 & 0.000128 & - & 2.300 & 5.568 & - & 41.31 & - & 41.40 & 60.24 \\
\hline 2 & 2 & 1638 & 0.653 & 63 & 0.0000132 & \begin{tabular}{|l|l} 
& 0.7278 \\
\end{tabular} & 2.953 & 5.745 & 11.37 & 51.41 & 22.12 & 41.23 & 57.93 \\
\hline 3 & 4 & 1632 & 1.302 & 53 & 0.000157 & 0.4342 & 3.602 & 6.829 & 19.06 & 52.74 & 36.14 & 41.06 & 48.36 \\
\hline 4 & 6 & 1624 & 1.943 & 48 & 0.0000173 & \begin{tabular}{|l} 
\\
\end{tabular} & 4.243 & 7.540 & 25.77 & 56.27 & 45.79 & 40.60 & 43.09 \\
\hline 5 & 8 & 1620 & 2.584 & 44 & 0.000189 & \begin{tabular}{|l|l} 
\\
\end{tabular} & 4.884 & 8.225 & 31.42 & 59.38 & 52.91 & 40.70 & 39.50 \\
\hline 6 & 10 & 1606 & 3.202 & 38 & 000219 & 0.2461 & 5.502 & \begin{tabular}{|l|}
9.524 \\
\end{tabular} & 33.62 & 57.77 & 58.20 & 40.72 & 33.83 \\
\hline
\end{tabular}

Table 3.1. Experimental Analysis without Porous medium

Table 3.2 shows the experimental analysis of Kirloskar 5BHP diesel engine with the porous medium. At maximum load $(10 \mathrm{~kg})$, we find the different kinds of efficiencies of porous medium engine are $44 \%$ Brake thermal efficiency, $72 \%$ Indicated thermal efficiency and 62\% Mechanical efficiency. When compared to conventional engine, all the efficiency values have been increased.

\begin{tabular}{|c|c|c|c|c|c|c|c|c|c|c|c|c|c|}
\hline s.No & $\begin{array}{c}\operatorname{LOAD} \\
(\mathbf{K g})\end{array}$ & $\mid$ & $\begin{array}{c}\text { BRAR } \\
\text { POWER } \\
\text { (kW }\end{array}$ & $\begin{array}{c}\text { TIME } \\
\text { TAKEN } \\
\text { FOR 10CC } \\
\text { FUEL } \\
\text { SUPPLIIDD } \\
\text { (Sec) }\end{array}$ & $\mid \begin{array}{c}\text { TOTAL FUEL } \\
\text { CONSUM } \\
(\mathrm{Kg} / \mathrm{s})\end{array}$ & \begin{tabular}{|c} 
SPECIFL \\
FUEL \\
CONSUMP \\
(Kog $/ \mathbf{k W}-\mathbf{h r})$
\end{tabular} & \begin{tabular}{|} 
INDICATED \\
POWER (kW)
\end{tabular} & $\begin{array}{c}\text { FUEL } \\
\text { POWER } \\
(\mathbf{k W})\end{array}$ & $\begin{array}{c}\text { BRAKE } \\
\text { THERMAL } \\
\text { EFFCIENCY } \\
\text { (\%) }\end{array}$ & $\begin{array}{c}\text { INDICATED } \\
\text { THERMAL } \\
\text { EFFCENCY } \\
\text { (\%) }\end{array}$ & $\begin{array}{l}\text { MECHANICAL } \\
\text { EFICIENCY } \\
\text { (\%) }\end{array}$ & \begin{tabular}{|l} 
VoL \\
EFr \\
$(\%)$
\end{tabular} & $\begin{array}{c}\text { AIR } \\
\text { FUL } \\
\text { RATIO }\end{array}$ \\
\hline 1 & 0 & 1648 & \begin{tabular}{|l|l|} 
& 0.000 \\
\end{tabular} & 63 & 0.000132 & . & 2.000 & \begin{tabular}{|l|l|}
5.745 \\
\end{tabular} & . & 34.81 & . & 38.67 & 54.67 \\
\hline 2 & 2 & 1630 & \begin{tabular}{|l|l|}
0.650 \\
\end{tabular} & 61 & 0.000136 & 0.7554 & 2.650 & 5.933 & 10.96 & 44.67 & 24.53 & 38.76 & 52.47 \\
\hline 3 & 4 & \begin{tabular}{|l|}
1628 \\
\end{tabular} & \begin{tabular}{|l|l|}
1.298 \\
\end{tabular} & 60 & \begin{tabular}{|l|l|}
0.000139 \\
\end{tabular} & 0.3844 & 3.298 & \begin{tabular}{|l|l|}
6.032 \\
\end{tabular} & 21.53 & 4.68 & 39.37 & 38.46 & 51.15 \\
\hline 4 & 6 & 1622 & $\mid 1.941$ & 55 & 0.000151 & 0.2806 & 3.941 & 6.580 & 29.49 & 59.88 & 49.25 & 37.53 & 45.59 \\
\hline 5 & 8 & 1618 & \begin{tabular}{|l|}
2.581 \\
\end{tabular} & 52 & $\mid 0.000160$ & 0.2232 & 4.581 & 6.960 & 37.08 & 65.82 & 56.34 & 37.62 & 43.10 \\
\hline 6 & 10 & 1616 & 3.222 & 50 & 0.000166 & 0.1859 & 5.222 & 7.238 & 44.52 & 72.15 & 61.70 & 37.31 & 41.04 \\
\hline
\end{tabular}

Table 3.2. Experimental Analysis with Porous medium

\subsection{Emission Analysis}

We have experimentally investigated the emission characteristics of IC Engine with and without inserting porous medium on cylinder head for various working load conditions by using Flue Gas Analyzer (Make : ENDEE ENGINEERS, Model Number : PA - 2400). The obtained results are shown in Table 3.3, 3.4.

The table 3.3 shows the exhaust gas emissions characteristics of IC engine for various loads. All the emission constituents are identified using flue gas analyzer. The nitrogen monoxide and Carbon dioxide present in the exhaust gases continuously increasing from no load to maximum load.

\begin{tabular}{|c|c|c|c|c|c|c|c|c|c|c|c|c|}
\hline $5 \mathrm{~N}_{0}$ & Losd & $\begin{array}{l}\text { No } \\
\text { (pre) }\end{array}$ & $C 0(0)$ & $02(\%)$ & $\begin{array}{l}50 ? \\
(\mathrm{me})\end{array}$ & & $\gamma(\omega)$ & $\begin{array}{c}\mathrm{TEO} \\
\mathrm{CO}\end{array}$ & $\begin{array}{l}\text { No: } \\
(\mathrm{mec})\end{array}$ & $\operatorname{Vid}$ & EFF (9) & $\begin{array}{l}\text { EARR } \\
\text { (mi) }\end{array}$ \\
\hline \multirow[b]{2}{*}{1} & \multirow[b]{2}{*}{0} & 181 & 02 & 14.1 & 4 & 32 & 32 & 164 & 0 & 60.7 & 6.6 & 17 \\
\hline & & 186 & 02 & 138 & 41 & 39 & 39 & 183 & 0 & 621 & 62 & 29 \\
\hline & \multirow[b]{2}{*}{2} & 181 & 0. & 13. & 48 & 42 & 42 & 201 & 0 & 6.7 & 616 & 27 \\
\hline & & 187 & 02 & 135 & 42 & 4 & 4 & 204 & 0 & 645 & 60.7 & 284 \\
\hline & \multirow[b]{2}{*}{ t } & 248 & 02 & 126 & 30 & 95 & 59 & 25 & 1 & \$? & 607 & 252 \\
\hline & & 37 & 02 & 128 & 33 & 32 & 52 & 20 & 0 & 666 & 602 & 25. \\
\hline & \multirow[b]{2}{*}{6} & 34 & 02 & 118 & $=$ & 66 & 66 & 23 & 7 & 62 & 993 & 2 \\
\hline & & 282 & 02 & 123 & 21. & 6 & 8 & 28 & 2 & 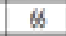 & 9 & 24 \\
\hline \multirow[b]{2}{*}{5} & \multirow[b]{2}{*}{8} & 366 & 02 & 115 & 14 & 79 & 79 & 29 & 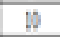 & 654 & 988 & 21 \\
\hline & & iH & $0 ?$ & 11.7 & 17 & 68 & 68 & 20 & 3 & 653 & 988 & 22 \\
\hline 6 & 10 & 485 & 01 & $w_{3}$ & 0 & 89 & 89 & 89 & W & 65.1 & 992 & 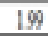 \\
\hline
\end{tabular}

Table 3.3. Emission levels for without Porous medium

The table 3.4 shows the exhaust gas emissions characteristics of IC engine for various loads. When compared to emissions of conventional, nitrogen monoxide and Carbon dioxide present in the exhaust gases continuously decreasing from no load to maximum load. Effluent value of the PM engine will be around $63 \%$. Similarly, Sulphur dioxide and nitrogen dioxide present in the exhaust gases continuously decreasing from no load to maximum load.

\begin{tabular}{|c|c|c|c|c|c|c|c|c|c|c|c|c|}
\hline$\$ N$ & $\begin{array}{l}\text { tood } \\
\text { (i) }\end{array}$ & $\begin{array}{l}\text { No } \\
\text { (nka) }\end{array}$ & $\left.\infty 0^{\circ}\right)$ & $0:(\%)$ & $\begin{array}{l}502 \\
\text { (fres) }\end{array}$ & $\cos \left(\theta^{\circ}\right.$ & $x(10)$ & $\begin{array}{l}\mathbb{T 2 0} 8 \\
10\end{array}$ & $\begin{array}{l}\text { S0: } \\
\text { (pre) }\end{array}$ & Vidis & घा) & $\begin{array}{l}\text { ENR } \\
\text { (mi) }\end{array}$ \\
\hline \multirow[b]{2}{*}{1} & \multirow[b]{2}{*}{0} & 45 & 01 & 198 & 31 & 0.7 & 0.9 & LII & 0 & 703 & 613 & 402 \\
\hline & & 4) & $0 !$ & 149 & 4 & 09 & 09 & $16 !$ & 0 & 7 & 69 & 39 \\
\hline \multirow[b]{2}{*}{2} & \multirow[b]{2}{*}{2} & 98 & 02 & 134 & is & 26 & 26 & 158 & 0 & 703 & 86 & 28 \\
\hline & & 100 & 02 & 132 & 36 & 28 & 28 & 185 & 0 & $\theta$ & 632 & 23 \\
\hline \multirow[b]{2}{*}{3} & \multirow[b]{2}{*}{4} & 1119 & 02 & 1) & 13 & 1 & 1 & 199 & 0 & 68 & 634 & 26 \\
\hline & & 119 & 02 & 132 & 37 & 3 & 3 & 191 & 0 & 468 & 63. & 208 \\
\hline \multirow[b]{2}{*}{1} & \multirow[b]{2}{*}{6} & $18 \%$ & $0 ?$ & 1.9 & 3 & 4 & 4 & 204 & 0 & (6) & 64 & 2.16 \\
\hline & & 13 & 02 & 126 & y & 38 & 38 & $x$ & 0 & 66 & 83.1 & 216 \\
\hline \multirow[b]{3}{*}{6} & \multirow[b]{3}{*}{110} & 174 & 02 & 11.7 & $n$ & 1 & 3 & 219 & 0 & 67 & 69.4 & 23 \\
\hline & & 176 & $0 !$ & 12 & $y$ & (4) & (3) & 219 & 0 & 69 & QS & (2) \\
\hline & & 169 & 01 & 12 & 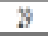 & 4.7 & 40 & 219 & 0 & 678 & 65 & 213 \\
\hline
\end{tabular}

Table 3.4. Emission levels for with Porous medium

\section{RESULTS \& DISCUSSION}

When compared to conventional engine, PM installed engine has reduced the percentage of total fuel consumption quantity and percentage of specific fuel consumption quantity by $13 \%$ and $12 \%$ respectively during part load operations as shown in figure 4.1, 4.2.

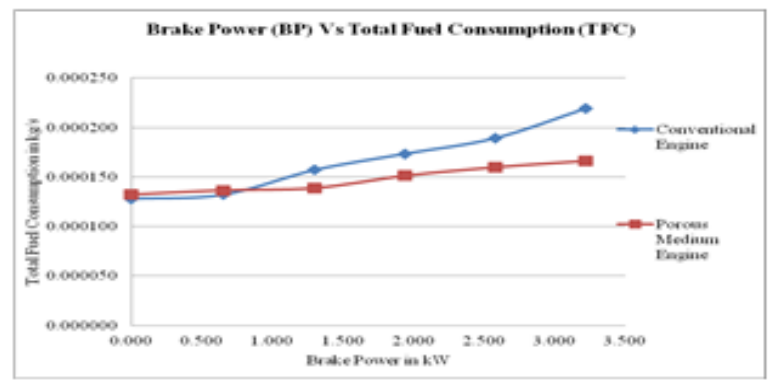

Fig.4.1. BP Vs TFC 


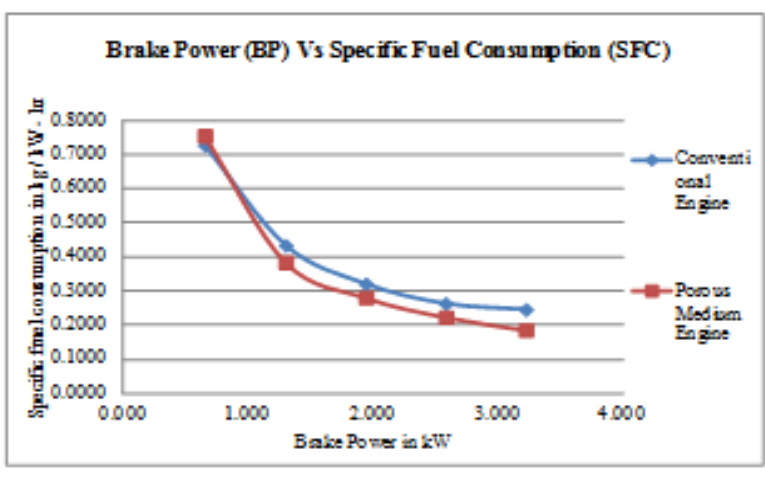

Fig.4.2. BP Vs SFC

When compared to conventional engine, PM installed engine has increased the percentage of BTE, ITE and ME by $12 \%, 6 \%$ and $8 \%$ respectively during various load operations as shown in figure $4.3,4.4$ and 4.5

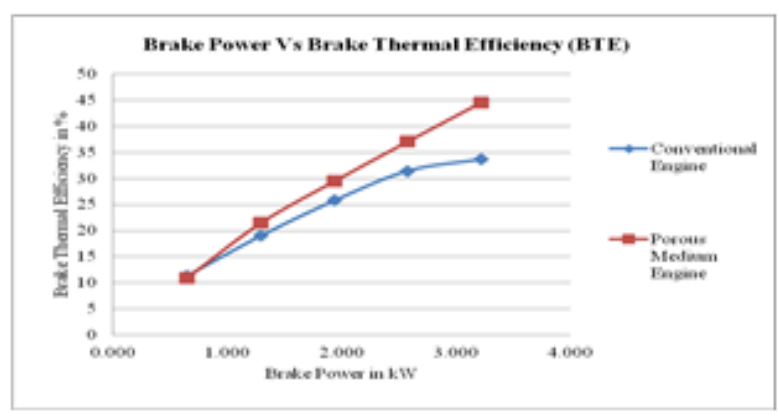

Fig.4.3. BP Vs BTE

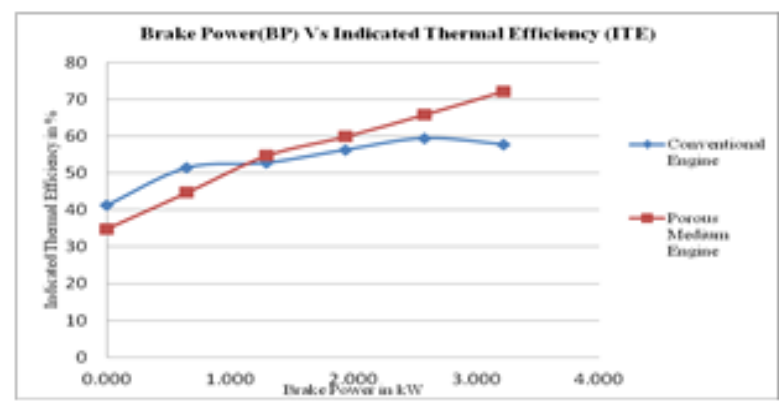

Fig.4.4. BP Vs ITE

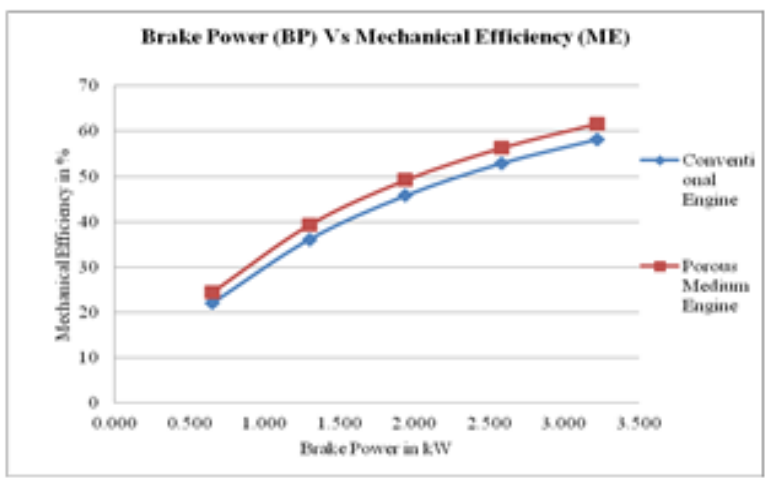

Fig.4.5. BP Vs ME

When compared to conventional engine, PM installed engine has reduced the percentage of $\mathrm{NOx}$ and $\mathrm{CO}_{2}$ by $56 \%$ and $43 \%$ respectively during various load operations as shown in figure 4.6 and 4.7. The Percentage of $\mathrm{SO}_{2}$ was consistently maintained in PM installed engine comparatively than conventional engine as shown in figure 4.8 .

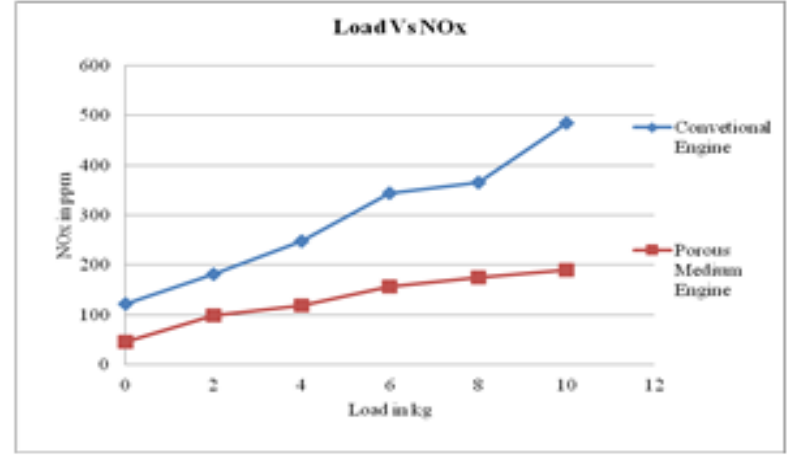

Fig 4.6. Load Vs Nox

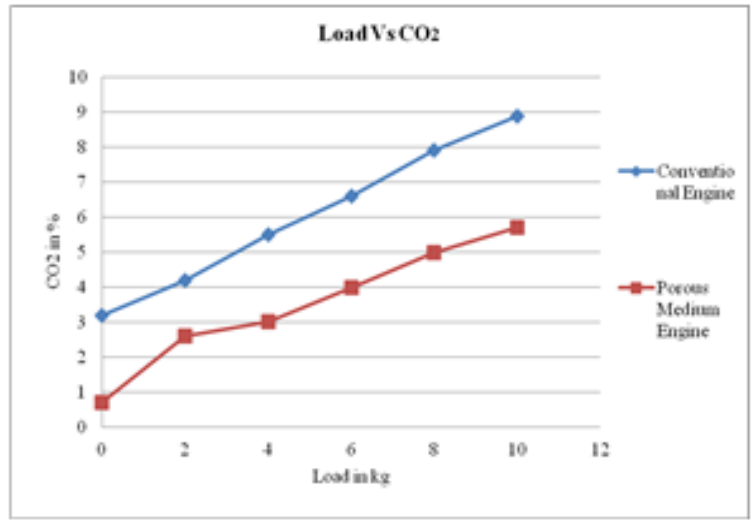

Fig. 4.7 Load Vs CO2

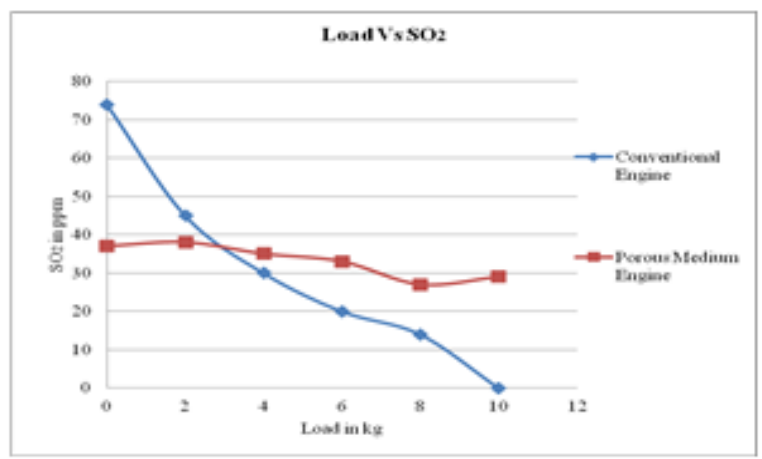

Fig. 4.8 Load Vs SO2

Investigation of the outcome obtained commencing the trials conducted on the engine with the intend changes of the cylinder head, which is straightforwardly enhances the largely competence and presentation of the engine giving enhancement in exhaust emissions. The graph plotted shows the relative enhanced competence with admiration to adjust in design of the cylinder head. All the above findings are claimed after conducting iterative testing and analyzing the investigational data. It is exclusive investigate work individual conducted and an tremendous advance towards the overall improvement of the engine competence which is the need of the existing development in the field of Automobile.

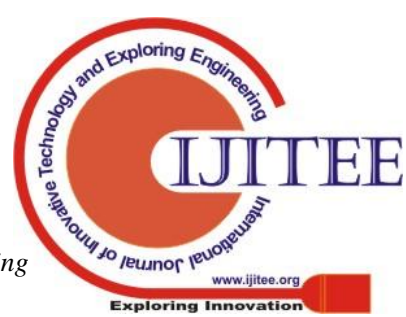




\section{CONCLUSION}

The Porous Medium Combustion Technology is an efficient technology for improving the emission as well as performance characteristics of the IC engine. Gun metal porous medium (35 $\mathrm{mm}$ x $16 \mathrm{~mm} \times 3 \mathrm{~mm}$ ) has been introduced at top of the IC engine cylinder head which is located $6 \mathrm{~mm}$ ahead of the fuel injector location for achieving the homogeneous combustion. Comparison of Performance and Emissions Characteristics of Conventional engine and PM engine has been analyzed with and without inserting the porous medium on top of the cylinder head. Reduction of total fuel consumption quantity up to $13 \%$, Specific fuel consumption quantity up to $12 \%$, increment in Brake thermal efficiency up to $12 \%$ and Indicated thermal efficiency up to $6 \%$ are obtained during part load operations. Mechanical efficiency has been increased up to $8 \%$, NOx level gets reduced up to $53 \%$ and $\mathrm{CO} 2$ level gets decreased up to $46 \%$ from no load to full load operations.

\section{REFERENCES}

1. Jeyakkannan, N., and B. Nagaraj. "Online Monitoring of Geological Methane Storage and Leakage Based on Wireless Sensor Networks." Asian Journal of Chemistry 26 (2014).

2. [2] Prof. Dr. Miroslaw Weclas, April 2004 "Strategy for intelligent Internal Combustion engine with homogeneous combustion in cylinder" ISSN 1616-0762 Sonderdruck Schriftenreihe der Georg-Simon-OhmFachhochschule Nürnberg Nr. 26.

3. Balvinder Budania, Virender Bishnoi May 2012 "A New Concept of I.C. Engine with Homogeneous Combustion in a Porous Medium" International Journal of Latest Trends in Engineering and Technology (IJLTET) ISSN: 2278-621X Vol. 1 Issue 1.

4. Kannan Chidambaram and Tamilporai Packirisamy (2009) "Smart Ceramic Materials for Homogeneous Combustion in Internal Combustion Engines - A Review" Thermal Science: Vol. 13 (2009), No. 3, pp. 153-163

5. C. Kannan \& P. Tamilporai (2011) "Enhancement of emission characteristics of a direct injection diesel engine through porous medium combustion technique" International Journal of Energy and Environment , Volume 2, Issue 5.

6. M. Abdul Mujeebu, M.Z. Abdullah, M.Z. Abu Bakar, A.A. Mohamad, M.K. Abdullah (2009) "Applications of porous media combustion technology - A review" Applied Energy 86 (2009) 1365-1375.

7. Lei Zhou, Mao-Zhao Xie, \& Kai Hong Luo (2014) "Numerical study of heat transfer and combustion in IC engine with a porous media piston region" Applied Thermal Engineering.

8. A Mohammadi, A.Jazayeri \& M.Ziabasharhagh Oct 2012 "Numerical Simulation of Combustion with Porous Medium in I.C. Engine" International Journal of Automotive Engineering Vol. 2, Number 4.

9. N. Ravi Kumar (2011) "Exergy Analysis of Porous Medium Combustion Engine Cycle" International Scholarly Research Network, ISRN Mechanical Engineering. Volume 2011, Article ID 542840.

10. Zhao Zhiguo \& Xie Maozhao Mar. 2008 "Numerical Study on the Compression Ignition of a porous medium engine" Springer Journal Sci China Ser E-Tech Sci | vol. $51 \mid$ no. 3 |277-287.

11. S. Vijaykant, Ajay K. Agrawal (2007), "Liquid fuel combustion within silicon-carbide coated carbon foam"
Experimental Thermal and Fluid Science 32 (2007) 117125.

12. Balakrishnan, Nagaraj, and K. Nisi. "A deep analysis on optimization techniques for appropriate PID tuning to incline efficient artificial pancreas." Neural Computing and Applications (2018): 1-10.

13. Marcelo J.S. de Lemos (2010) "Analysis of turbulent combustion in inert porous media "International Communications in Heat and Mass Transfer 37 (2010) 331-336

14. M. Abdul Mujeebu, M.Z. Abdullah, M.Z. Abu Bakar, A.A. Mohamad, M.K. Abdullah (2009) "A review of investigations on liquid fuel combustion in porous inert media" Progress in Energy and Combustion Science 35 (2009) 216-230

15. W.G.Wang, D.W.Lyons, N.N.Clark, And M .Gautam (2000) "Emissions from Nine Heavy Trucks Fueled by Diesel and Biodiesel Blend without Engine Modification" Environ. Sci. Technol. 2000, 34, 933-939

16. Afsharvahid, P.J. Ashman, B.B. Dally (2008) "Investigation of NOx conversion characteristics in a porous medium" Combustion and Flame 152 (2008) 604-615.

17. Tarun K. Kayal, Mithiles Chakravarty (2006) "Modeling of trickle flow liquid fuel combustion in inert porous medium" International Journal of Heat and Mass Transfer 49 (2006) 975-983.

18. Susie Wood, Andrew T. Harris (2008) "Porous burners for lean-burn applications" Progress in Energy and Combustion Science 34 (2008) 667-684

19. Macek Jan \& Polasek Milos "Porous Medium Combustion In Engines May Contribute To Lower Nox Emissions" Code No F02V147.

20. Hongsheng Liu, Maozhao Xie \& Dan Wu (2009) "Simulation of a porous medium (PM) engine using a two-zone combustion model" Applied Thermal Engineering.

21. F. Avdic, M. Adzic, F. Durst (2010) "Small scale porous medium combustion system for heat production in households" Applied Energy 87 (2010) 2148-2155

22. Jan Macek, Miloš Polášek "Simulation Of Porous Medium Combustion In Engines" Research Center project, Ministry of Education, Czech Republic.

23. Jan Macek, Miloš Polášek "Via Homogeneous Combustion to Low Nox Emission" Josef Božek Research Center, Czech Technical University in Prague.

24. José E.A. Coutinho, Marcelo J.S. de Lemos (2012) "Laminar flow with combustion in inert porous media" International Communications in Heat and Mass Transfer 39 (2012) 896-903

25. M.Weclas, J. Cypris, and T. M. A. Maksoud (2012) "Thermodynamic Properties of Real Porous Combustion Reactor under Diesel Engine-Like Conditions" Journal of Thermodynamics Volume 2012, Article ID 798104, 11 pages.

26. F. Illán, M. Alarcon (2010) "Numerical analysis of combustion and transient heat transfer processes in a two-stroke SI engine" Applied Thermal Engineering 30 (2010) $2469-2475$

27. Arunn Narasimhan (2013) "Essentials of Heat and Fluid flow in Porous Media" ISBN 9789382127215, Imprint Ane Books Pvt. Ltd.

28. Ashok A. Dhale, Gajanan K. Awari, and Mahendra P. Singh (2010) "Analysis of Internal Combustion Engine with a New Concept of Porous Medium Combustion for the Future Clean Engine" Thermal Science: Year 2010, Vol. 14, No. 4, pp. 943-956 